\title{
FP_Tree ASSOCIATION RULE MINING ECOMMERCE PRODUCT ADVERTISING EFFORTS TO IMPROVE PRODUCT BRAND SALES STRATEGY TO SUPPORT ECOMMERCE BUSINESS IN INDONESIA
}

\author{
by \\ Wanra Tarigan ${ }^{1}$, Thamrin Thamrin², Lismardiana Sembiring ${ }^{3}$, Iswanto Sembiring ${ }^{4}$, Harlen Silalahi ${ }^{5}$,Tulus \\ Pramita Sihaloho ${ }^{6}$ \\ 1,2,3,4,5,6 sistem Informasi,Sekolah Tinggi Ilmu Komputer Medan, \\ Jln.Jamin Ginting no.285 Padang Bulan Medan,20155,indonesia \\ Email: ${ }^{1}$ wansibro@yahoo.com ${ }^{2}$ thamrin@itnb.ac.id, \\ ${ }^{3}$ lismardianasembiring@gmail.com, ${ }^{4}$ harlen.silalahi10@gmail.com, \\ ${ }^{5}$ sembiring.gurky64@gmail.com, ${ }^{6}$ sihalohotulus@ gmail.com
}

\begin{tabular}{l}
\hline \hline Article Info \\
\hline Article history: \\
Received July 9, 2021 \\
Revised August 20, 2021 \\
Accepted Sept 11, 2021
\end{tabular}

Keywords:

ecommerce, FP_Tree, Assosiasi Rule Mining , Iklan, Bukalapak, Shopee, Lazada, JD.Id, Blibli.Com, Tokopedia

\begin{abstract}
The increasing growth of e-commerce in Indonesia makes research on online marketplaces an interesting topic to research. Several factors, such as buyer reviews and ratings, the ease of buying and selling transactions, shipping costs (postage), the reputation of the e-commerce platform, and also the reputation of the store itself (seller) are considered by buyers in choosing an online store. The more platforms there are, the more intense the competition between online marketplaces will be. With that, many start-up companies B2B (Business to Business), or B2C (Business to Customer), C2B (Customer to Business), $\mathrm{C} 2 \mathrm{C}$ (Customer to Customer), which stated that many of their products were sold with fantastic sales figures. But there are also some products that need to be developed for sales due to the lack of product advertisements being broadcast and launched on a large scale because these products are considered good for future prospects and profitable for the company.
\end{abstract}

This is an open access article under the CC BY-SA license.

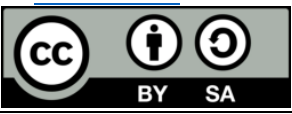

Corresponding Author:

Wanra Tarigan

Sistem Informasi,Sekolah Tinggi Ilmu Komputer Medan, Indonesia

Email: wansibro@yahoo.com

\section{INTRODUCTION}

E-commerce is electronic commerce that utilizes technology in carrying out buying, selling, marketing and service activities (Bein, Graha, and Pangestu 2020)for products, services, and information through various computer networks. Businesses today use the internet, intranets, extranets, and other networks to support every step of the commercial process, from everything from advertising, sales and consumer support on the web to payment security mechanisms to ensure delivery and payment processes are completed.(Watson and Kennedy 2006).

The existence of internet technology provides convenience to users by only business transactions are carried out directly, but using technology. Internet media has begun to be widely used as a medium for doing business by looking at its contribution to efficiency. (Veleva 2019)Efficiency itself is an advantage in conducting transactions using the internet because it saves time.(Puji Lestari 2018) Because with technology the seller does not have to meet directly with the buyer, such as with transportation constraints. (Jack M. Wilson 2020)The next benefit of internet media (online 
shopping sites) for consumers is shopping without having to leave home.(Rahayu and Day 2017) Or if consumers want to compare prices from one store to another, consumers don't have to come(Ara 2017)

The increasing growth of e-commerce in Indonesia makes research on online marketplaces an interesting topic to research.(Kartiwi et al. 2018) Several factors, such as buyer reviews and ratings, the ease of buying and selling transactions, shipping costs (postage), (Adyanto and Santosa 2018)the reputation of the e-commerce platform, and also the reputation of the store itself (seller) are considered by buyers in choosing an online store. (Zuroni and Goh 2012)The more platforms there are, the more intense the competition between online marketplaces will be. Therefore, each online marketplace must be able to show its uniqueness and advantages in order to survive in the e-commerce market.(Watson and Kennedy 2006)

Industrial Reality, the large size of e-commerce in Indonesia is also(Bunardi, Naga, and Arisandi 2019) marked by the increasing number of unique advertising (Shen 2012)variations that even seem eccentric to break old habits. In addition to visualization, jingles are also a strong influence to make advertisements stick to consumers' memories. "Shopee with its marketing strategy has succeeded in capturing the public's attention through the Goyang Shopee campaign. (Agustin and Hellianto 2020)Their jingle is iconic and has successfully attracted attention. Of the five age segments in the category of the most creative offline online advertising ideas,(Agustin and Hellianto 2020) all of them chose Shopee. After that, Lazada, Bukalapak, and Tokopedia in various age ranges.(Safira, Kusyanti, and Aryadita 2017)

Various variations of successful campaigns stick in the minds of consumers, including Goyang Shopee, Shopping Festival, to Money Storm. In terms of domicile, Shopee dominates in six big cities, followed by Lazada, Tokopedia and Bukalapak behind it. (Setyaningsih 2017)By looking at data from surveys released in several categories, big brands that compete to offer various promotions at attractive prices have succeeded in becoming consumers' choices. (Girotra and Kaushik 2018)It is not surprising that the e-commerce industry has started to focus on names such as Shopee, Tokopedia, (Budyastuti and Iskandar 2018)Lazada to Bukalapak, (Ni Kadek Suryani 2020)so that people are very familiar with online shopping, which one is the cheapest, whose campaign is the most memorable, until it is most frequently accessed, is the reality of the e-commerce industry. With the behavior of product brands in e-commerce, (R. E. Goldsmith and E. Bridges 2000)it is very beneficial for companies that have types of services such as Bussiness to Business (B2B), Business to Customer (B2C), Customer to Business (C2B) and Customer to Customer ( $\mathrm{C} 2 \mathrm{C})$. competition in the manufacture of product advertisements so that the best-selling products are sold in the online market.(Lip-Sam and Hock-Eam 2011)

\section{RESEARCH METHOD}

Fp-Growth

Mining without candidate generation is an FP-Growth technique using data structures. By using this method, the database scan is only done twice, no need to repeat it. The data will be represented in the form of FP-Tree. After the FP-Tree is formed, a very good data structure for Frequent itemset will be obtained. FP-Tree is an excellent data structure for frequent Pattern mining, this structure provides complete information to form Frequent Patterns. Items that are not frequent (infrequent) no longer exist in the use of FP-tree

Construction of FP-Tree from a set of transaction data, the FP-Growth algorithm will be applied to find a significant Frequent itemset. (Lismardiana 2018)The FP-tree algorithm is divided into three main steps, namely:

1. Generation Phase Conditional Pattern Base The Conditional Pattern Base is a subdatabase that contains path prefixes (lines e: 1 prefix) and patterns (suffix patterns). Generating conditional pattern base is obtained through the FP-tree that has been built previously.

2. Conditional FP-tree Generation Stage At this stage, the support count of each item in each conditional pattern base is added up, then each item that has a support count greater than the minimum support count will be generated with a conditional FP-tree.

3. Frequent itemset search stage if the conditional FP-tree is a single path, then the frequent itemset is obtained by combining items for each conditional FP-tree. If it is not a single path, then FP-growth is generated recursively. These three stages are the steps that will be taken to get the frequent itemset.

4. By using FP-Growth, we can do Pettern Frequent itemset without taking a long time. 
Vol.1 No.3 October 2021, pp: 225-232

ISSN: 2798-3463 (Printed) | 2798-4079 (Online)

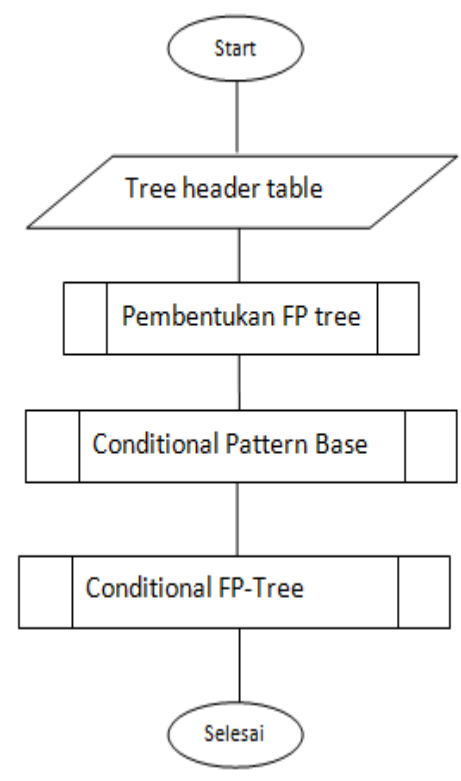

\section{Rule Mining Association Analysis}

Fugure 1. Flowchart FP_Growth

Association rules are in data mining that find frequent itemsets in the database. Association of data mining rules is a mechanism in data mining in association rules, the implication expression of the form $\mathrm{X} \rightarrow \mathrm{Y}$ where $\mathrm{X}$ is $\mathrm{Y}$. The antecedent and consequent are specified domain items I. The introduction and consequent are a set of items from domain I. Thus $\mathrm{X} \cap \mathrm{Y}=$. The support of the item set is defined as the ratio of the number of transactions containing the item set to the total number of transactions. The trust of association rule $\mathrm{X} \rightarrow \mathrm{Y}$ is the probability that $\mathrm{Y}$ transaction contains association rule mining algorithm X, Arora K. Rakesh and Badal Dharmendra10 The formula to find the support and confidence values is:(Mulyawan, Vionelsy, and Sutrisno 2020)

$$
\begin{aligned}
& \text { a. Support } \\
& \text { Support }(\mathrm{A} \rightarrow \mathrm{B})=\frac{\text { Jumlah Transaksi Mengandung A dan B }}{\text { Jumlah Total Transaksi }} \\
& \text { b. Confidence } \\
& \text { Support }(\mathrm{A} \rightarrow \mathrm{B})=\frac{\text { Jumlah Transaksi Mengandung A dan B }}{\text { Jumlah Total Transaksi }}
\end{aligned}
$$

Association analysis is defined as a process to find all association rules that meet the minimum requirements for support (minimum support) and minimum requirements for confidence (minimum confidence).

\section{RESULTS AND DISCUSSION}

Data source comes from: https://www.androidcame.com/2020/08/7-categories-product-terlaris-di.html Source ecommerceiq.asia which published Bram's writings on Monday, August 10, 2020 .

Table1. Percentage of Ecommerce Sales in Indonesia 


\begin{tabular}{|c|c|c|c|c|c|c|}
\hline & Abliblicom & Bukalapak & D. ID & LAZADA & hopee & tokopedia \\
\hline Mobile \& Electronics & $21 \%$ & $25 \%$ & $15 \%$ & $20 \%$ & $13 \%$ & $22 \%$ \\
\hline Fashion & $17 \%$ & $16 \%$ & $11 \%$ & $19 \%$ & $24 \%$ & $12 \%$ \\
\hline Beauty & $4 \%$ & $4 \%$ & $11 \%$ & $9 \%$ & $12 \%$ & $5 \%$ \\
\hline Health \& Wellness & $3 \%$ & $2 \%$ & $3 \%$ & $3 \%$ & $5 \%$ & $5 \%$ \\
\hline Mom \& baby & $8 \%$ & $4 \%$ & $10 \%$ & $8 \%$ & $8 \%$ & $4 \%$ \\
\hline Toys & $5 \%$ & $5 \%$ & $5 \%$ & $5 \%$ & $5 \%$ & $9 \%$ \\
\hline Groceries & $17 \%$ & $9 \%$ & $19 \%$ & $10 \%$ & $11 \%$ & $11 \%$ \\
\hline Lifestyle and Hobby & $8 \%$ & $10 \%$ & $7 \%$ & $7 \%$ & $8 \%$ & $10 \%$ \\
\hline Home \& Living & $7 \%$ & $8 \%$ & $10 \%$ & $9 \%$ & $8 \%$ & $9 \%$ \\
\hline Sports & $4 \%$ & $6 \%$ & $3 \%$ & $4 \%$ & $3 \%$ & $4 \%$ \\
\hline Travel & $5 \%$ & $3 \%$ & $3 \%$ & $2 \%$ & $2 \%$ & $3 \%$ \\
\hline Automotive & $0 \%$ & $7 \%$ & $2 \%$ & $3 \%$ & $1 \%$ & $4 \%$ \\
\hline \multirow[t]{2}{*}{ Others } & $0 \%$ & $1 \%$ & $0 \%$ & $1 \%$ & $1 \%$ & $2 \%$ \\
\hline & \multicolumn{5}{|c|}{$\begin{array}{c}\text { Figure 7: The most popular product categories on ecommerce platforms in Indonesia; } \\
\text { ecommercelQ E-Marketplace Indonesia Survey }\end{array}$} & \\
\hline
\end{tabular}

In table 1 above is the data record of the best-selling products in the marketplace in Indonesia with the percentage of the best-selling products using several e-commerce platforms such as: blibli.com, Bukalapak, JD.id, Lazada, Shopee and Tokopedia, where each percentage figure describes sales data. products of any existing e-commerce services. In the analysis of the data above that there are also some products with low percentages but the possibility of a lack of advertising in each product on each e-commerce service so that the product percentage figure is very low for each ecommerce service. (Kamepalli and Bandaru 2019)The percentage data in the table above is used as criteria data. which will be processed with the following information: 1 . A1 $>20 \%, \mathrm{~B} 1>17 \%, \mathrm{C} 1>12 \%,>9 \%=\mathrm{D} 1,>6 \%=\mathrm{E} 1,<6 \%=\mathrm{F} 1$. :

Table2. Transaction ID

\begin{tabular}{|l|l|}
\hline No.Rec & Item \\
\hline TID 1- 10 & A1,B1,E1,F1 \\
\hline TID11-20 & A1,C1,D1,F1 \\
\hline TID 21-30 & B1,D1,C1,F1 \\
\hline TID31-40 & B1,D1,E1,F1 \\
\hline TID41-50 & A1,C1,E1 \\
\hline TID51-60 & A1,C1,D1,E1 \\
\hline
\end{tabular}

Table 2 above states that the results of the Transaction Process data are divided into 6 (six) classification groups, namely: TID 1-TID 10: serial number 1 to 10 in column A, where A = Bilibli.com, TID 11-20 serial number 1- 10 in column B, where B = Bukalapak, TID 21-30 serial numbers 1-10 in column C, where C = JD.id, TID 31-40 serial numbers 1-10 in column D, where D = Lazada, TID 41 -50 serial numbers 1-10 in column E, where $\mathrm{E}=\mathrm{Shopee,} \mathrm{and}$ TID 50-60 serial numbers 1-10 in column F, where F = Tokopedia. Furthermore, in table 2 above, the formation of association rule mining is applied by applying the FP_Growth method with build FP_Tree in the image below: 
Vol.1 No.3 October 2021, pp: 225-232

ISSN: 2798-3463 (Printed) | 2798-4079 (Online)

DOI: https://doi.org/10.53625/ijss.v1i3.415

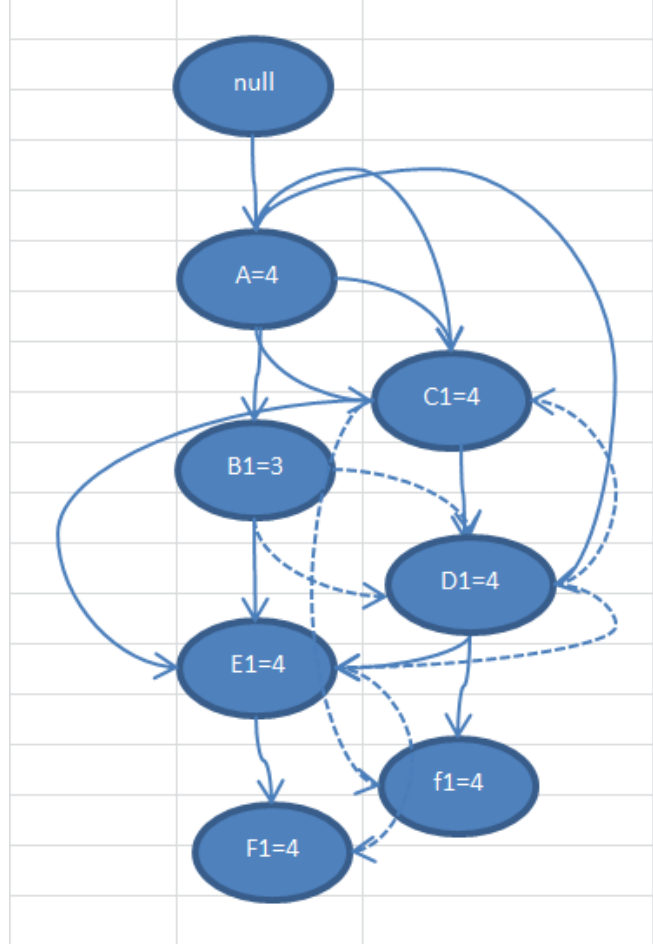

Figure2. FP_Grwoth/FP_Tree

From the FP_Tree above, there are several items that can be seen in the FP_Tree node line which is the result of generating Frequent Itemset on TID records in table 2. From the FP_Tree above, it is concluded that the item/itemset that generates Frequent Item/Itemset $\mathrm{A} 1=4, \mathrm{C} 1=4, \mathrm{~B} 1=3, \mathrm{D} 1=4, \mathrm{E} 1=4, \mathrm{~F} 1=4, \mathrm{~F} 1=4$ where advertising products are displayed by several start-up (Vora Assit et al. 2021)companies such as blibli.com, Bukalapak, JD.id, Shopee, Lazada and Tokopedia, all of which have unique characteristics. themselves in making digital advertising ad impressions to attract customers to buy products from their company. Detailed data can be seen in table 3 below:

\section{Table 3. Generate Frequent Itemset}

\begin{tabular}{|c|c|}
\hline K1 Item & Frequent Item \\
\hline $\mathrm{A} 1$ & 4 \\
\hline $\mathrm{B} 1$ & 3 \\
\hline $\mathrm{E} 1$ & 4 \\
\hline $\mathrm{F} 1$ & 4 \\
\hline $\mathrm{C} 1$ & 4 \\
\hline $\mathrm{D} 1$ & 4 \\
\hline
\end{tabular}

In table 3 above, the results of data processing using FP_Growth, namely FP_Tree generate Frequent Itemset to a table. The results of Generate Frequent Itemset in table 3 above which have a high frequent number are: A1, E1, F3, C3, D1. So that after sorted as in the table below:

Table 4. List Generate Frequent Itemset

\begin{tabular}{|l|l|}
\hline K1 Item & Frequent Item \\
\hline B1 & 3 \\
\hline A1 & 4 \\
\hline E1 & 4 \\
\hline F1 & 4 \\
\hline C1 & 4 \\
\hline D1 & 4 \\
\hline
\end{tabular}


In table 4 above, the list of results for the number of frequent items/itemsets in FP_Tree states that the highest frequent values are: A1, E1, F3, C3, D1. After getting the number of frequent itemset results in table 4 above, they are in the group:

Table 5. Assosiasi Rule Mining

\begin{tabular}{|c|l|l|l|}
\hline K1 Item & $\begin{array}{l}\text { Frequent } \\
\text { Item }\end{array}$ & Min Support 50\% & Min.Confidence 60\% \\
\hline K1 Item & $\begin{array}{l}\text { Frequent } \\
\text { Item }\end{array}$ & Min Support 50\% & Min.Confidence 60\% \\
\hline A1 & 4 & $7 \%$ & $48 \%$ \\
\hline B1 & 3 & $5 \%$ & $36 \%$ \\
\hline E1 & 4 & $7 \%$ & $48 \%$ \\
\hline F1 & 4 & $7 \%$ & $48 \%$ \\
\hline C1 & 4 & $7 \%$ & $48 \%$ \\
\hline D1 & 4 & $7 \%$ & $48 \%$ \\
\hline
\end{tabular}

In table 5 above, the results from the list of association rule mining minimum support $50 \%$ \& minimum confidence $60 \%$ there are several parts as follows: 1 . Frequent itemset results with support value 7\%: A1, E1, F1, C1, $\mathrm{D} 1$ and support value $5 \%$ is $\mathrm{B} 1$, the confidence value is $48 \%$ : $\mathrm{A} 1, \mathrm{E} 1, \mathrm{~F} 1, \mathrm{C} 1, \mathrm{D} 1$ and $\mathrm{B} 1$ the confidence value is $36 \%$. Thus, it is concluded that those with the highest support and confidence values are those with a value of 4 , followed by a value of 3 . Which has a support value of $7 \%$ and $5 \%$. And the confidence value has a value of $48 \%$ and $36 \%$.

\section{CONCLUSION}

From the data processing carried out using FP_Growth in FP_Tree can produce a decision in accordance with the output table of the rule mining association in the table below:

Table 6.Out Put dari Asosiasi Rule Mining I

\begin{tabular}{|l|l|l|}
\hline Rule Mining & Nama Produk & Ecommerce \\
\hline A1 $>21 \%$ & Mobile\&Electronics & Blibli.com \\
\hline & & Bukalapak \\
\hline & & Tokopedia \\
\hline & Fashion & Shopee \\
\hline & Fashion & Blibli.com \\
\hline & Groceries & Blibli.com \\
\hline & Fashion & Lazada \\
\hline C1 $>12 \%$ & Groceries & JD.id \\
\hline & Fashion & Bukalapak \\
\hline & Fashion & JD.id \\
\hline & Beauty & JD.id \\
\hline
\end{tabular}

In table 6 the output of the rule mining association, I stated that product brand sales increased by promoting the product brand so that the percentage of sales increased the same in several e-commerce such as: Blibli.com, Bukalapak, Tokopedia, Shopee, Lazada, JD.id .(Ernawati et al. 2021) this is of course with a variety of campaigns, digital advertisements, promotions on social media, IG, Twitter, Facebook to inviting famous artists to lure customers to access e-commerce services that are already available and well-known in Indonesia.

Table 7.Out Put dari Asosiasi Rule Mining II

\begin{tabular}{|c|l|l|}
\hline Rule Mining & Nama Produk & Ecommerce \\
\hline D1 $>9 \%$ & Lifestyle and Hobby & Bukalapak \\
\hline \multirow{2}{*}{$\begin{array}{r}>6 \%=\mathrm{E} 1, \\
<6 \%=\mathrm{F} 1\end{array}$} & Mom \& Baby & JD.id \\
\cline { 2 - 3 } & Groceries & Lazada \\
\cline { 2 - 3 } & Home \& Living & Tokopedia \\
\hline
\end{tabular}


International Journal of Social Science (IJSS)

Vol.1 No.3 October 2021, pp: 225-232

ISSN: 2798-3463 (Printed) | 2798-4079 (Online)

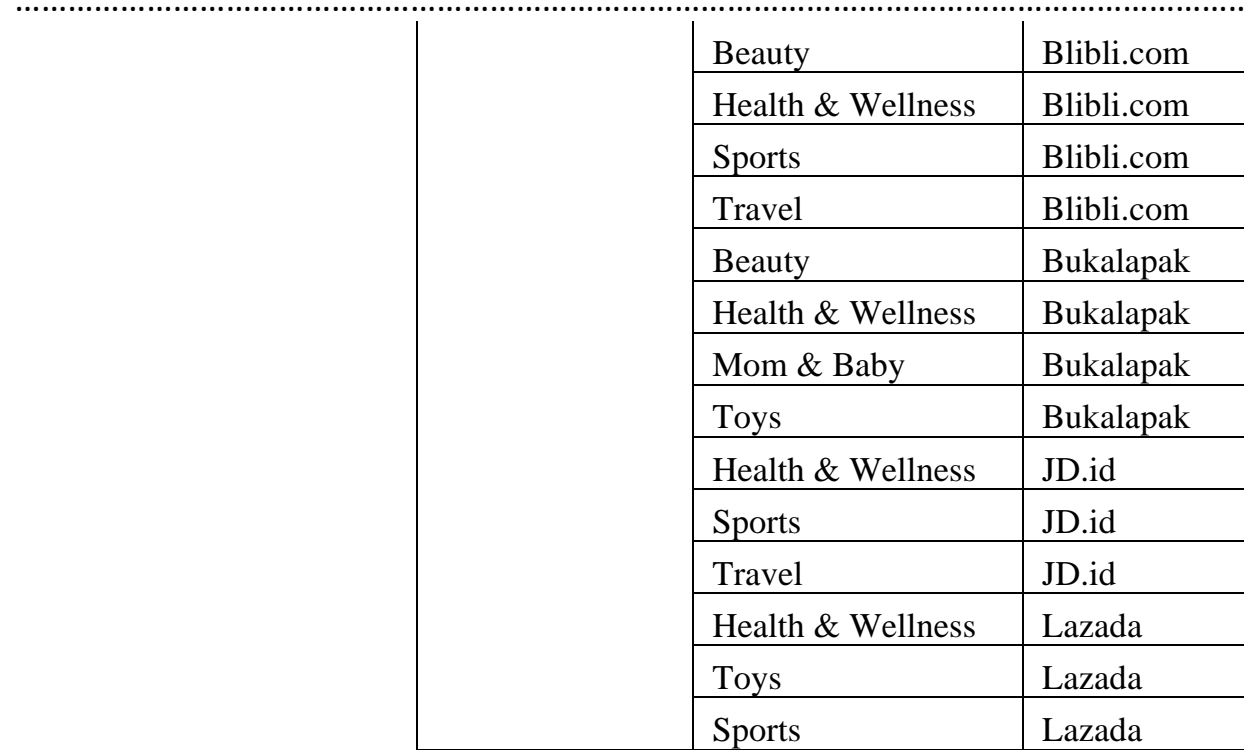

In table 7 the Out Put of the Rule Mining II Association states that from the data in table 1 above, there are still several product brands in e-commerce that still have sales percentage figures below $6 \%$. This percentage figure below $6 \%$ is the center of attention by e-commerce parties to carry out large-scale campaign actions because the percentage value below $6 \%$ has a frequent item set of $4 \mathrm{x}$ in all e-commerce services such as: Blibli.com, Bukalapak, Tokopedia, Shopee, Lazada, JD. en. it is possible that this product brand is favored by the e-commerce community, only because the product brand is less aggressively promoted by each e-commerce party so that the product brand is not selling well, even though in terms of user needs it is very important, even very much needed by the community, especially product brands. : Health \& wellness, Mom \& Baby, Toys and Sprots all of these are household and individual needs.

\section{REFERENCES}

[1] Adyanto, Brian Cahyo, and Suryono Budi Santosa. 2018. "PENGARUH KUALITAS LAYANAN, BRAND IMAGE , HARGA DAN KEPERCAYAAN PRODUK TERHADAP KEPUTUSAN PEMBELIAN (Studi Layanan E-Commerce Berrybenka.Com).” Diponegoro Journal of Management 7 (1): 1-20. http://ejournals1.undip.ac.id/index.php.

[2] Agustin, Cindy Ayu, and Gracia Reveria Hellianto. 2020. "Pengaruh Reputasi Terhadap Minat Beli Produk Skincare Di Shopee." Business Economic, Communication, and Social Sciences (BECOSS) Journal 2 (1): 39-52. https://doi.org/10.21512/becossjournal.v2i1.6050.

[3] Ara, Affreen. 2017. "Growth of E-Commerce in India," no. July.

[4] Bein, Adrian Sean, Yuliana Isma Graha, and Anggit Panji Pangestu. 2020. "Pandawan Website Design Based Content Management System As Media E-Commerce Transaction." Aptisi Transactions On Technopreneurship (ATT) 2 (1): 87-97. https://doi.org/10.34306/att.v2i1.73.

[5] Budyastuti, Triyani, and Diah Iskandar. 2018. "The Influence of Usefulness , Easy of Use and Trust Using ECommerce To User Behaviour ( Case Study To Lazada . Com Consumers )." Journal of Marketing and Consumer Research 46: 78-83.

[6] Bunardi, Benny, Dali Santun Naga, and Desi Arisandi. 2019. "Pengembangan Aplikasi E-Commerce Produk Lokal Dan Data Kependudukan Pada Desa Giritengah, Borobudur." Computatio : Journal of Computer Science and Information Systems 3 (1): 77. https://doi.org/10.24912/computatio.v3i1.4274.

[7] Ernawati, Iin, Nurhafifah Matondang, Universitas Pembangunan, Nasional Veteran, Pondok Labu, and Jakarta Selatan. 2021. "PRODUCT BUNDLING APPLICATION TO SUPPORT IMPLEMENTATION OF ASSOCIATION RULE MINING USING FP-GROWTH," no. 355.

[8] Girotra, Renu, and Tanuja Kaushik. 2018. "Recruiting Challenges of E-Commerce Start-Ups in India." Journal of $\begin{array}{llllll}\text { Organisation and Human } & \text { Behaviour } & 7 & \text { (2): }\end{array}$ https://search.proquest.com/docview/2138650570?accountid=14570\%0Ahttp://primo49man.hosted.exlibrisgroup.com/openurl/MAN/MAN_UB_service_page?url_ver=Z39.882004\&rft_val_fmt=info:ofi/fmt:kev:mtx:journal\&genre=article\&sid=ProQ:ProQ\%3Aabiglobal\&atitle=Recrui.

[9] Jack M. Wilson. 2020. "Marketing Strategies for EBusiness" 9 (2): 2019. 
[10] Kamepalli, Sujatha, and Srinivasa Bandaru. 2019. "Weighted Based Frequent and Infrequent Pattern Mining Model for Real-Time E-Commerce Databases." Advances in Modelling and Analysis B 62 (2-4): 53-60. https://doi.org/10.18280/ama_b.622-404.

[11] Kartiwi, Mira, Husnayati Hussin, Mohd Adam Suhaimi, Mohamed Razi Mohamed Jalaldeen, and Mohammad Ruhul Amin. 2018. "Impact of External Factors on Determining E-Commerce Benefits among SMEs in Malaysia." Journal of Global Entrepreneurship Research 8 (1): 1-12. https://doi.org/10.1186/s40497-018-01057.

[12] Lip-Sam, Thi, and Lim Hock-Eam. 2011. "Estimating the Determinants of B2B E-Commerce Adoption among Small \& Medium Enterprises." International Journal of Business and Society 12 (1): 15-30.

[13] Lismardiana. 2018. "Penerapan Algortima Apriori \& Fp-Growth Untuk Pengambilan Keputusan Di Pemko Medan." Jurnal Pembangunan Perkotaan 6 (1): 46-54. http://ejpp.balitbang.pemkomedan.go.id/index.php/JPP.

[14] Mulyawan, Bagus, Vionelsy, and Tri Sutrisno. 2020. "Product Recommendation System on Building Materials Shopping Using FP-Growth Algorithm." IOP Conference Series: Materials Science and Engineering 1007 (1). https://doi.org/10.1088/1757-899X/1007/1/012144.

[15] Ni Kadek Suryani, Ni Putu Nina Eka Lestari. 2020. "Pengaruh Website Quality, Trust, Dan E - Service Quality Terhadap Loyalitas Konsumen Pada E-Commerce Pengguna Situs Shopee . Co . Id." TIERS Information Technology Journal 1 (2): 34-43.

[16] Puji Lestari, Fibria Anggraini. 2018. "Pengaruh Web E-Commerce, Kualitas Produk Dan Kualitas Layanan Terhadap Kepuasan Konsumen.” Sosio E-Kons 10 (1): 87. https://doi.org/10.30998/sosioekons.v10i1.2411.

[17]R. E. Goldsmith and E. Bridges. 2000. "E-Talling vs Retailing: Using Attitudes to Predict Online Buying Behavior." Quarterly Journal of Electronic Commerce 1 (3): 245-53.

[18] Rahayu, Rita, and John Day. 2017. "E-Commerce Adoption by SMEs in Developing Countries: Evidence from Indonesia." Eurasian Business Review 7 (1): 25-41. https://doi.org/10.1007/s40821-016-0044-6.

[19] Safira, Cindy Farah, Ari Kusyanti, and Himawat Aryadita. 2017. "Analisis Kualitas Layanan Website Bukalapak Terhadap Kepuasan Pengguna Menggunakan E-S-Qual.” Jurnal Pengembangan Teknologi Informasi Dan Ilmu Komputer 1 (12): 1813-21.

[20] Setyaningsih, Oktania. 2017. "Pengaruh Persepsi Kualitas Pelayanan E-Commerce Terhadap Kepuasan Pelanggan, Kepercayaan Dan Loyalitas Pada Produk Fashion.” Jurnal Bisnis Dan Manajemen 14 (2): 67. https://doi.org/10.20961/jbm.v14i2.4126.

[21] Shen, Jia. 2012. "Social Comparison, Social Presence, and Enjoyment in the Acceptance of Social Shopping Websites." Journal of Electronic Commerce Research 13 (3): 198-212.

[22] Veleva, Petya. 2019. "Internet Advertising - a Marketing Tool Supporting E-Commerce." Trakia Journal of Sciences 17 (Suppl.1): 883-90. https://doi.org/10.15547/tjs.2019.s.01.145.

[23] Vora Assit, Bhrantav, N J Patel Professor, Acharya Motibhai Patel, and N N Jani Dean. 2021. "Review-Based Product Automated Recommendation System in E-Commerce Using Improved Frequent Pattern Mining and Artificial Intelligence." International Journal of Research in Electronics and Computer Engineering 6 (2): 133136.

[24] Watson, Susan E, and Gary A Kennedy. 2006. "Website Usage Information for Rural-Based Website Usage Information for Rural-Based E-Commerce Start-Ups *."

[25]Zuroni, Md Jusoh, and Hai Ling Goh. 2012. "Factors Influencing Consumers' Attitude Towards E-Commerce Purchases Through Online Shopping." International Journal of Humanities and Social Science 2 (4): 223-30. 